\title{
RANCANG BANGUN DAN IMPLEMENTASI AUTOMATIC TRANSFER SWITCH (ATS) MENGGUNAKAN ARDUINO UNO DAN RELAI
}

\section{DESIGN AND IMPLEMENTATION AUTOMATIC TRANSFER SWITCH (ATS) USING ARDUINO UNO AND RELAY}

\author{
Robinzon Pakpahan ${ }^{1}$, Dadan Nur Ramadan ${ }^{2}$, Sugondo Hadiyoso ${ }^{3}$ \\ 1,2,3 Diploma 3 Teknik telekomunikasi, Fakultas Ilmu Terapan, Universitas Telkom \\ 1robinzon126@gmail.com, ․ㅡㅁadannr@telkomuniversity.ac.id, $\underline{\text { Sugondo@telkomuniversity.ac.id }}$
}

\begin{abstract}
Abstrak
Sistem cadangan/backup catudaya mutlak diperlukan pada perangkat elektronika yang memerlukan energi listrik yang tidak terhenti. Cadangan catudaya digunakan untuk menggantikan sumber utama PLN. Pada penerapannya diperlukan sebuah perangkat pendukung berupa Automatic Transfer switch (ATS) untuk melakukan pensaklaran dari sumber utama ke cadangan catu daya atau sebaliknya. Pada paper ini, dibahas realisasi perangkat ATS berbasis mikrokontroler yang bekerja berdasarkan pembacaan arus dan tegangan. Sistem ini juga dilengkapi dengan komunikasi berbasis LAN untuk mengirim data monitoring. Setelah dilakukan pengujian, perangkat ATS dapat mengukur arus dan tegangan dengan rata-rata kesalahan $3,76 \%$ dan $0,21 \%$ pada pengukuran generator set dan sumber PLN. Pengujian lainnya, sistem relai dapat berfungsi untuk memindahkan sumber listrik dari sumber utama ke sumber cadangan atau sebaliknya.
\end{abstract}

Kata kunci: Cadangan Catudaya, Automatic Transfer Switch (ATS), mikrokontroler, relai.

\begin{abstract}
Backup power supply system is absolutely necessary in the electronic device that requires electrical energy continuously. Backup power supply is used to replace the primary in this case is PLN source. Practically, needed a support device which are called Automatic transfer switch (ATS) to perform switching from the primary source to the backup power supply or contrary. In this paper, discussed the realization of ATS based on microcontroller device that works on the basis of current and voltage readings. The system also comes with a LAN-based communications to send data monitoring. After testing, ATS device can measure current and voltage with an average error of $3.76 \%$ and $0.21 \%$ on the measurement of generator sets and PLN. Other testing, relay systems can function to switch the power source of the main sources to backup sources or contrary.
\end{abstract}

Keywords: Backup power supply, Automatic Transfer Switch (ATS), microcontroler, relay.

\section{PENDAHULUAN}

Energi listrik sudah menjadi kebutuhan utama untuk mengoprasikan perangkat-perangkat elektronika, banyak perangkat di bidang telekomunikasi, industri dan kesehatan memerlukan energi listrik secara kontinyu atau tidak boleh terhenti, sehingga ditambahkan sumber listrik cadangan sebagai backup, yang dapat dipergunakan apabila sumber listrik utama mengalami gangguan. Perpindahan energi listrik, dari sumber utama ke cadangan tidak boleh meyebabkan perangkat 
elektronika mati karena adanya jeda waktu perpindahan, sehingga ditambahkan sistem pendukung berupa Automatic Transfer switch (ATS).

ATS merupakan sebuah sistem yang terdiri dari beberapa perangkat listrik, diantaranya terdiri dari beberapa buah relai, timer dan magnetic kontraktor[1-3], ATS berfungsi untuk memindahkan sumber tegangan listrik ke sumber tegangan listrik lainnya secara otomatis, tanpa membuat beban kehilangan aliran listrik.

Beberapa penelitian sudah dilakukan pada ATS dan perkembangannya, diantaranya penelitian pada fungsi ATS [1-3], dan beberapa penelitian yang melakukan dengan penambahan sistem mikrokontroler pada perangkat ATS[4-6], mikrokontroler yang ditambahkan berfungsi sebagai pengontrol atau monitoring pada ATS.

Pada penelitian ini pembuatan ATS tidak menggunakan timer dan magnetic kontraktor seperti beberapa penelitian sebelumnya, tetapi cukup menggunakan mikrokontroler berupa Arduino UNO, yang disusun dengan transformator CT, sensor pembaca tegangan dan modul relai, sedangkan untuk monitoringnya digunakan sensor arus dan modul ethernet sebagai sarana komunikasi secara LAN, penggunaan modul ethernet adalah untuk menyimpan data-data hasil pengukuran di database yang dapat dipergunakan untuk keperluan monitoring, sehingga informasi dari alat pengontrol dapat diakses melalui jaringan LAN.

\section{DASAR TEORI}

\subsection{Arduino}

Arduino merupakan salah satu jenis board mikrokontroler yang banyak digunakan untuk pembuatan perangkat otomasi. Pada penelitian ini jenis Arduino yang digunakan adalah Arduino UNO. Arduino ini menggunakan chip ATMEGA328 sebagai CPU utamanya yang dapat diprogram menggunakan Bahasa $\mathrm{C}$ melalui aplikasi Arduino IDE.

Arduino UNO difungsikan untuk membaca nilai tegangan, mengontrol relai, kontrol display LCD dan mengirim data melalui modul LAN. Pada Gambar 1 adalah board Arduino yang sebagai modul kendali utama pada penelitian ini.

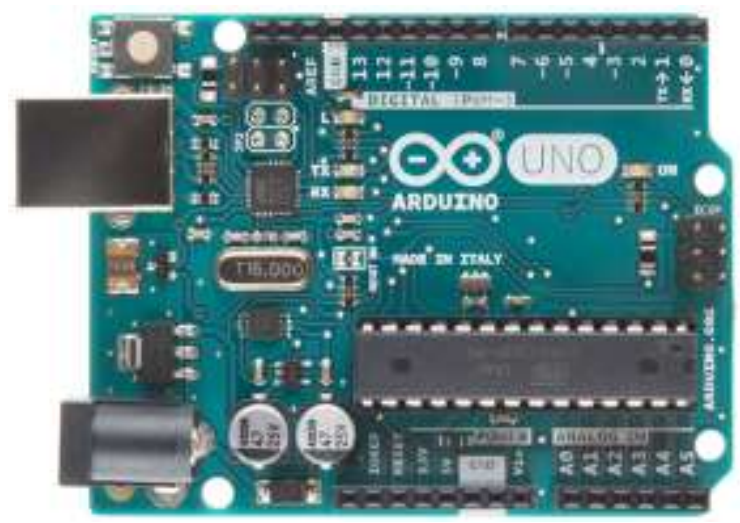

Gambar 1. Arduino UNO[7]

\subsection{Relai}

Relai adalah komponen elektronika yang dapat berfungsi untuk melakukan logika switching [8]. Relai adalah saklar yang dioperasikan secara elektromagnetik melalui sinyal elektrik. Jenis relai berdasar Contact Point yaitu Normally Close (NC) dan Normally Open (NO). Pada peneltian ini jenis normally close digunakan pada cadangan catudaya dan normally open dihubungkan pada sumber PLN. Relai secara logika dikontrol melalui Arduino untuk melakukan pensaklaran sesuai kondisi yang dikehendaki pada program. 


\section{AUTOMATIC TRANSFER SWITCH (ATS)}

Dengan menggabungkan sebuah mikrokontroler, rangkaian relai dan rangkaian pembaca tegangan menjadi sebuah sistem yang dapat berfungsi sebagai Automatic Transfer switch (ATS), pada Gambar 2 adalah blok diagram sistem dari penggabungan tersebut;

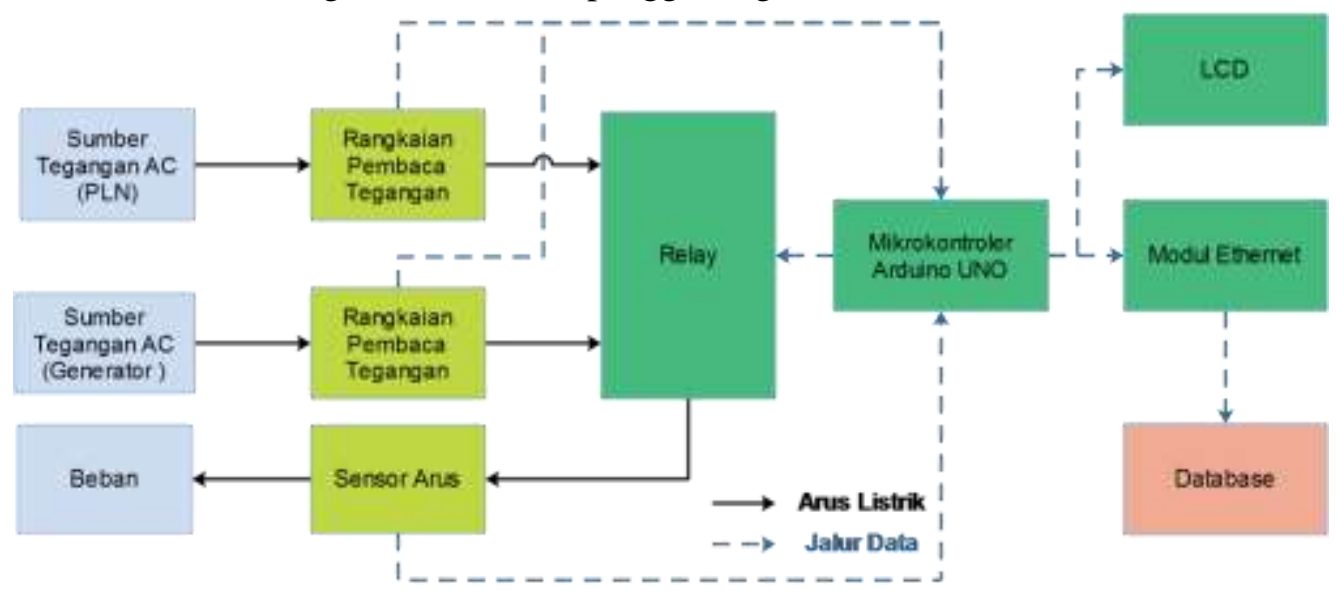

Gambar 2. Blok Sistem ATS

Rangkaian pembaca tegangan ditempatkan diantara sumber tegangan dan relai, rangkaian pembaca tegangan ini, memiliki beberapa fungsi, diantaranya untuk menurunkan tegangan AC dari PLN dan sumber cadangan (generator set) dan juga berfungsi untuk menyesuaikan nilai arus dan tegangan dari sumber AC, sehingga nilainya dapat dibaca menggunakan proses ACD pada pin analog mikrokontroler, dimana mikrokontroler yang dipergunakan yaitu Arduino UNO.

Rangkain pembaca tegangan, terdiri dari beberapa komponen diantaranya;

1. Transformator

2. Rangkaian pembagi tegangan

Pada Gambar 3 adalah sebuah transformator bertipe CT, yang dipergunakan untuk menurunkan tegangan dari 220 volt menjadi 12,7 volt, dikarenakan maksimal tegangan yang dapat dibaca oleh input ADC pada Arduino adalah 5 volt, maka diperlukan rangkaian pembagi tegangan untuk menurunkan tegangan output transformator.

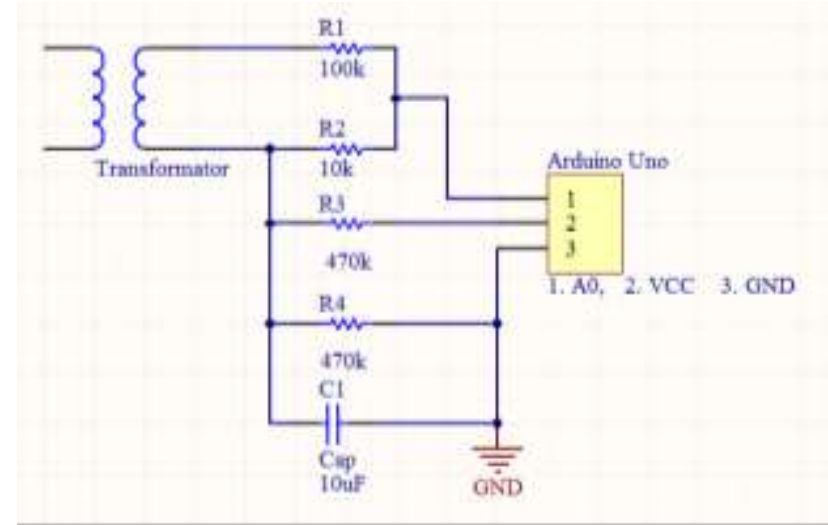

Gambar 3. Rangkaian pembaca nilai tegangan

Nilai keluaran tegangan dari trafo adalah sebesar 12.7 Volt, dan tegangan harus dimasukan kedalam rangkaian pembagi tegangan dengan nilai R1 dan R2 adalah 10k ohm dan 100k ohm agar 
Arduino dapat mengolah nilai tegangan pada Arduino Uno, berikut perhitungan yang dipergunakan pada rangkaian pembagi tegangan;

$$
\begin{aligned}
\text { Peak voltage output } & =\mathrm{R} 1 /(\mathrm{R} 1+\mathrm{R} 2) * \text { Peak voltage input } \\
& =10 \mathrm{k} \mathrm{ohm} /(10 \mathrm{k} \mathrm{ohm}+100 \mathrm{k} \mathrm{ohm}) * 12.7 \text { volt }
\end{aligned}
$$

Nilai tegangan 1.15 volt yang diperoleh dari hasil perhitungan diatas, kemudian dipergunakan sebagai nilai acuan dalam melakukan pengukuran oleh mikrokontroler, dengan menggunakan konsep ADC dengan maksimal data 10 bit yaitu 1023 (1024-1).

$$
\begin{aligned}
\text { Nilai_ADC } & =(\text { Vin } / \text { Vreff }) * \text { maksimal_data } \\
& =(1.15 \text { volt } / 5 \text { volt }) * 1023 \\
& =234.26 \\
& =234
\end{aligned}
$$

Pada bagian pengontrol pada sumber tegangan, dikarenakan menggunakan 2 buah sumber listrik yang berbeda yaitu PT. PLN dan sumber cadangan (generator-set), maka bagian ini disusun menggunakan relai 4 channel, pada Gambar 4 adalah rangkaian relai yang dirancang;
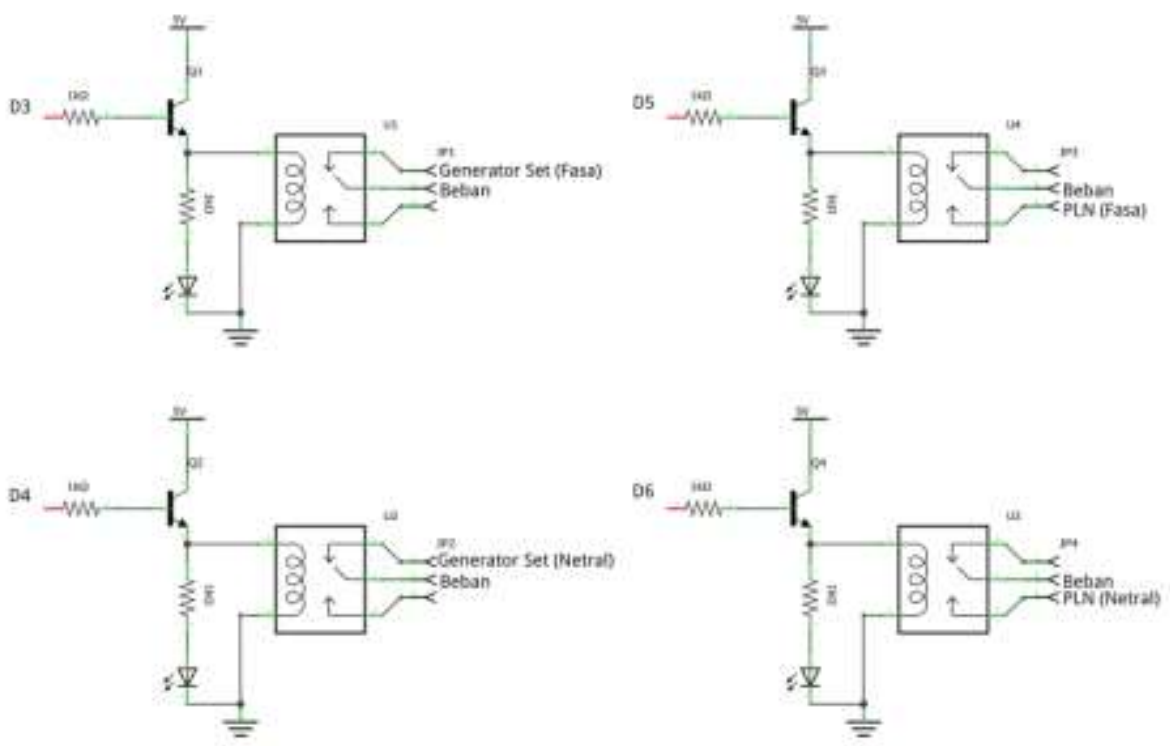

Gambar 4. Rangkaian relai sebagai pengontrol sumber tegangan

Pada gambar 5 adalah relai dibuat dengan menggunakan transistor BJT dengan tipe NPN, dimana transistor dengan tipe NPN akan bekerja jika diberi tegangan atau diberi logika HIGH dari Arduino UNO, berikut gambar relai pengontrol sumber listrik yang dibuat.

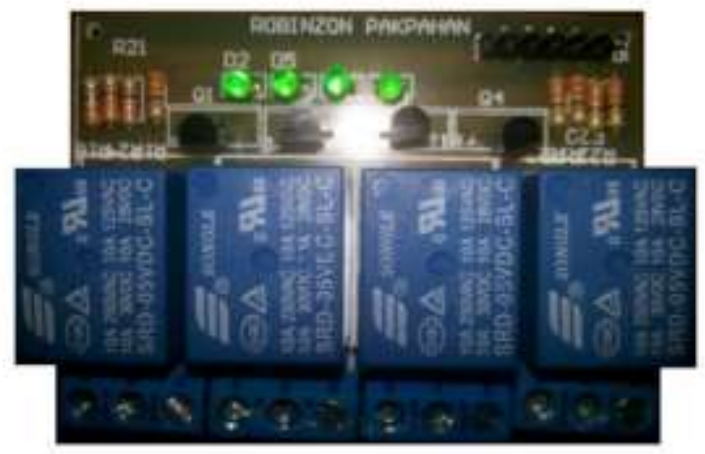

Gambar 5. Relai pengontrol sumber tegangan 
Dengan menggunakan parameter nilai pada rangkaian pembaca tegangan, Arduino UNO akan mengukur nilai tegangan dari sumber cadangan terlebih dahulu, jika nilai tegangan yang diperoleh sebesar 220 volt makan beban akan mendapatkan arus dari sumber cadangan, tetapi apabila nilai tegangan dari sumber cadangan lebih kecil dari 220 Volt, maka Arduino UNO akan menggerakan relai dengan cara memberikan logika HIGH pada relai, sehingga menyebabkan beban mengalami perpindahan sumber tegangan, dari sumber cadangan (generator set) ke sumber tegangan dari PLN, pada Gambar 6 adalah flowchart cara kerja dari sistem yang dibuat;

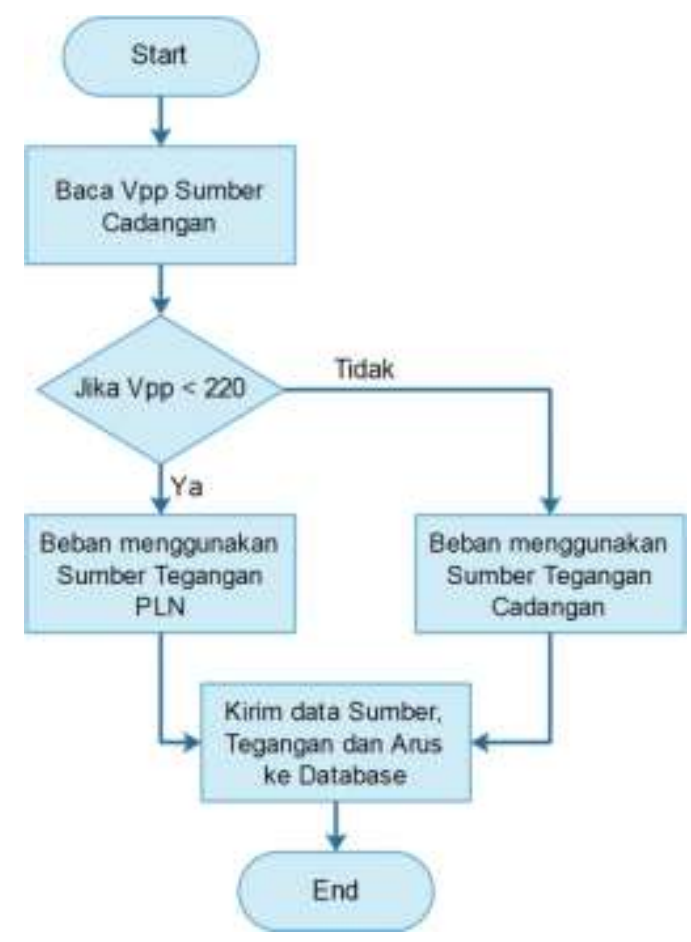

Gambar 6. Flowchart sistem

Pada bagian komunikasi, Arduino Ethernet Shield dipergunakan sebagai interface ke jaringan LAN, sehingga proses pengiriman data yang memuat informasi tentang penggunaan sumber tegangan, besar nilai tegangan dan arus yang dipergunakan dapat tersimpan di database, dan informasi tersebut dapat di akses menggunakan halaman website, diagram pengiriman data dapat dilihat pada Gambar 7 berikut;

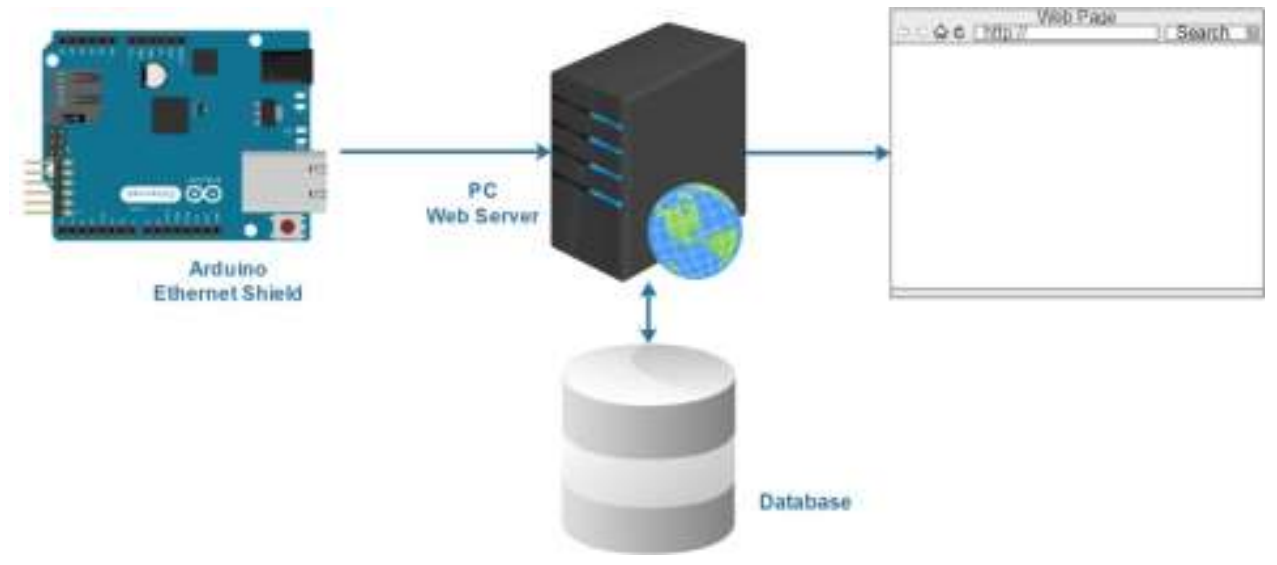

Gambar 7. Blok sistem pengiriman informasi ke database 


\section{HASIL DAN PEMBAHASAN}

\subsection{Pengujian Transformator CT}

Pengujian dilakukan pada setiap bagian dari perangkat, dengan untuk mengetahui kehandalan perangkat yang sudah dibuat, diantaranya pengujian pengukuran tegangan dan arus dengan melakukan perbandingan hasil pembaca tegangan pada alat yang dibuat, dengan alat ukur berupa multimeter.

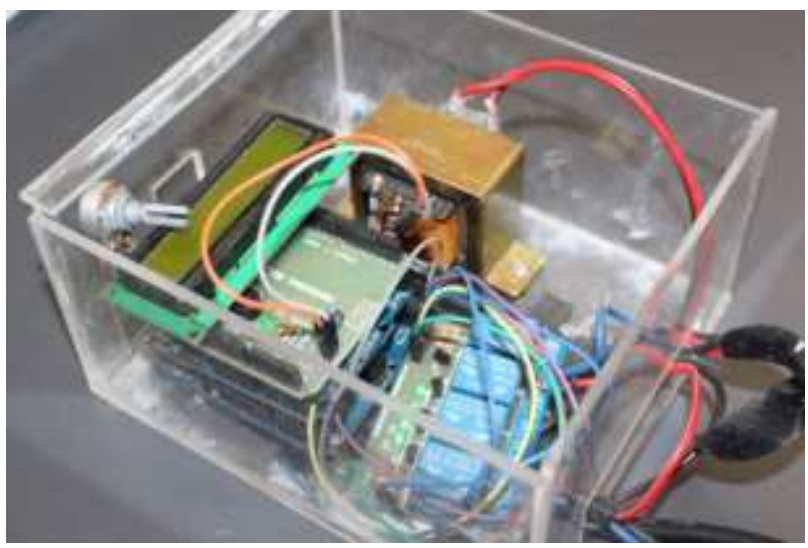

Gambar 8. Automatic Transfer Switch (ATS) yang dibuat

Pengujian transformator dilakukan bertujuan untuk mengetahui tingkat performansi transformator yang dipilih, dalam melakukan proses penurunan tegangan dan memastikan nilai tegangan dapat dibaca oleh pin analog pada Arduino UNO, berikut skema pengujian transformator;

Tabel 1. Pengujian Transformator CT

\begin{tabular}{|c|c|c|c|}
\hline No & $\begin{array}{c}\text { Nilai Tegangan dari } \\
\text { Sumber (volt) }\end{array}$ & $\begin{array}{c}\text { Nilai Tegangan Output } \\
\text { Trafo (volt) }\end{array}$ & $\begin{array}{c}\text { Nilai ADC pada pin } \\
\text { Analog Arduino UNO }\end{array}$ \\
\hline 1. & 235 & 13.13 & 1.20 \\
\hline 2. & 228 & 12.66 & 1.16 \\
\hline 3. & 222 & 12.11 & 1.12 \\
\hline 4. & 219 & 11.80 & 1.10 \\
\hline 5. & 205 & 9.15 & 1.04 \\
\hline
\end{tabular}

\subsection{Pengukuran Tegangan pada Sumber Listrik PLN}

Pengujian pengukuran tegangan yang dilakukan terhadap sumber listrik dari PLN dengan cara menggunakan beban dengan listrik yang berbeda-beda, untuk mengetahui tingkat kestabilan pengukuran tegangan.

Tabel 2. Pengujian Pengukur Tegangan

\begin{tabular}{|c|c|c|c|c|}
\hline No & Daya Beban & Nilai pada Multimeter & Nilai pada sensor & $\%$ error \\
\hline 1 & 0 Watt & 228 & 228 & 0.00 \\
\hline 2 & 0 Watt & 228 & 228 & 0.00 \\
\hline 3 & 0 Watt & 228 & 227 & 0.44 \\
\hline 4 & 0 Watt & 228 & 228 & 0.00 \\
\hline 5 & 0 Watt & 228 & 227 & 0.44 \\
\hline 6 & 300 Watt & 222 & 221 & 0.45 \\
\hline 7 & 300 Watt & 221 & 221 & 0.00 \\
\hline 8 & 300 Watt & 221 & 220 & 0.45 \\
\hline 9 & 300 Watt & 221 & 221 & 0.00 \\
\hline 10 & 300 Watt & 222 & 220 & 0.00 \\
\hline 11 & 350 Watt & 221 & 221 & 0.45 \\
\hline 12 & 350 Watt & 221 & 221 & 0.00 \\
\hline 13 & 350 Watt & 221 & 223 & 0.00 \\
\hline 14 & 350 Watt & 224 & 223 & 0.45 \\
\hline 15 & 350 Watt & 224 & & 0.45 \\
\hline
\end{tabular}


Berdasarkan Tabel 2 pengujian diatas dapat diambil kesimpulan bahwa kesalahan pengukuran dengan beban yang berbeda-beda nilai error terbesar adalah $0.45 \%$, dan rata-rata hasil pengujian keseluruhan nilai error adalah $0.21 \%$.

\subsection{Pengukuran Tegangan pada Sumber Listrik Generator Set}

Pengujian pengukuran tegangan yang dilakukan terhadap sumber listrik dari Generator Set dengan cara menggunakan beban dengan listrik yang berbeda-beda, untuk mengetahui tingkat kestabilan pengukuran tegangan.

Tabel 3. Pengujian Pengukur Tegangan

\begin{tabular}{|c|c|c|c|c|}
\hline No & Daya Beban & $\begin{array}{c}\text { Nilai pada } \\
\text { Multimeter }\end{array}$ & $\begin{array}{c}\text { Nilai pada } \\
\text { sensor }\end{array}$ & \% error \\
\hline 1 & 0 Watt & 228 & 229 & 0.44 \\
\hline 2 & 0 Watt & 228 & 230 & 0.87 \\
\hline 3 & 0 Watt & 228 & 229 & 0.44 \\
\hline 4 & 0 Watt & 227 & 229 & 0.87 \\
\hline 5 & 0 Watt & 228 & 229 & 0.44 \\
\hline 6 & 300 Watt & 228 & 240 & 5.00 \\
\hline 7 & 300 Watt & 228 & 241 & 5.39 \\
\hline 8 & 300 Watt & 228 & 240 & 5.00 \\
\hline 9 & 300 Watt & 227 & 240 & 5.42 \\
\hline 10 & 300 Watt & 228 & 240 & 5.00 \\
\hline 11 & 350 Watt & 227 & 240 & 5.42 \\
\hline 12 & 350 Watt & 227 & 240 & 5.42 \\
\hline 13 & 350 Watt & 227 & 241 & 5.81 \\
\hline 14 & 350 Watt & 227 & 240 & 5.42 \\
\hline 15 & 350 Watt & 227 & 240 & 5.42 \\
\hline
\end{tabular}

Berdasarkan tabel pengujian diatas dapat diambil kesimpulan bahwa kesalahan pengukuran dengan beban yang berbeda-beda nilai error terbesar adalah $5.81 \%$, dan rata-rata hasil pengujian keseluruhan nilai error adalah $3.76 \%$.

\subsection{Relai sebagai Pengontrol Sumber Listrik}

Relai berfungsi sebagai switch yang berfungsi untuk memindahkan sumber listrik dari PLN ke sumber listrik lain, atau sebaliknya. Pengujian Relai dengan Arduino Uno dilakukan agar mengetahui performasi kestabilan relai dalam melakukan pengontrol pada sumber listrik. Pengujian relai dilakukan dengan mengetahui status perpindahan relai terhadap sumber listrik dapat berjalan dengan baik, berikut Gambar 9 adalah proses pengujiannya.

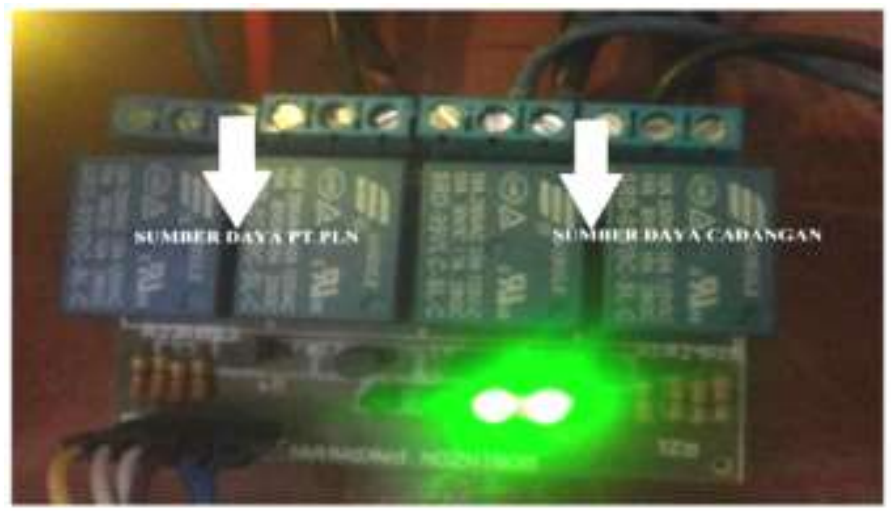

Gambar 9. Relai meneruskan sumber listrik dari cadangan (generator set) 
Pada Gambar 5. Flowchart sistem diatas, relai yang diberikan logika HIGH oleh Arduino Uno akan aktif, ketika Perangkat mengukur tegangan pada sumber listrik cadangan lebih besar dari 220 Volt maka relai akan secara otomatis memindahkan pemakaian sumber listrik terhadap sumber listrik cadangan (generator set). Namun ketika perangkat mengukur nilai tegangan pada sumber listrik cadangan (generator set) lebih kecil dari 220 Volt maka relai akan secara otomatis memindahkan sumber listrik ke PLN, seperti pada Gambar 10 dberikut.

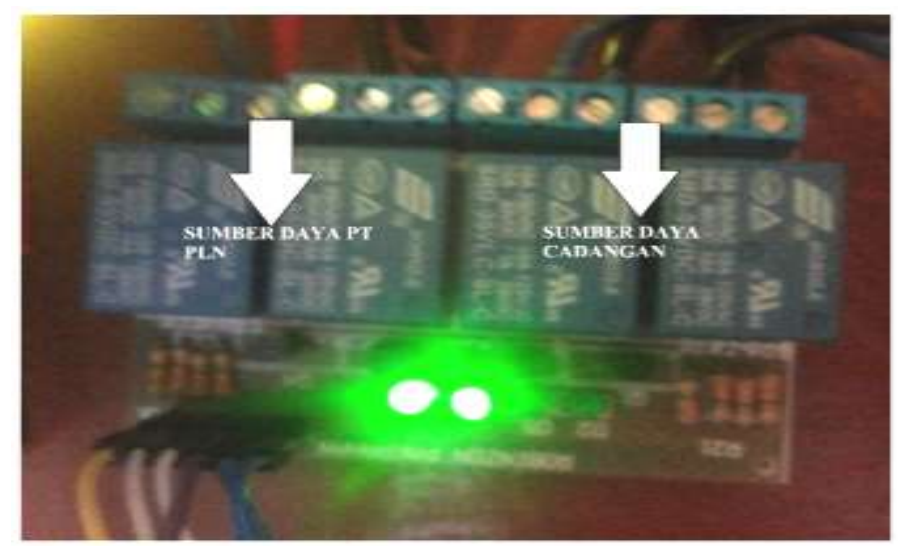

Gambar 10. Relai meneruskan sumber listrik dari PLN

Pengujian keseluruhan sistem seperti pada Gambar 11. Dilakukan dengan cara merubah-rubah nilai tegangan pada sumber cadangan (generator set) dengan rentan nilai antara 200 volt sampai dengan 230 volt pada rangkaian pembaca tegangan pada Generato Set, dengan tujuan untuk melihat kemampuan ATS yang dibuat dalam melakukan perpindahan sumber arus listrik secara otomatis, tanpa membuat beban kehilangan aliran listrik.

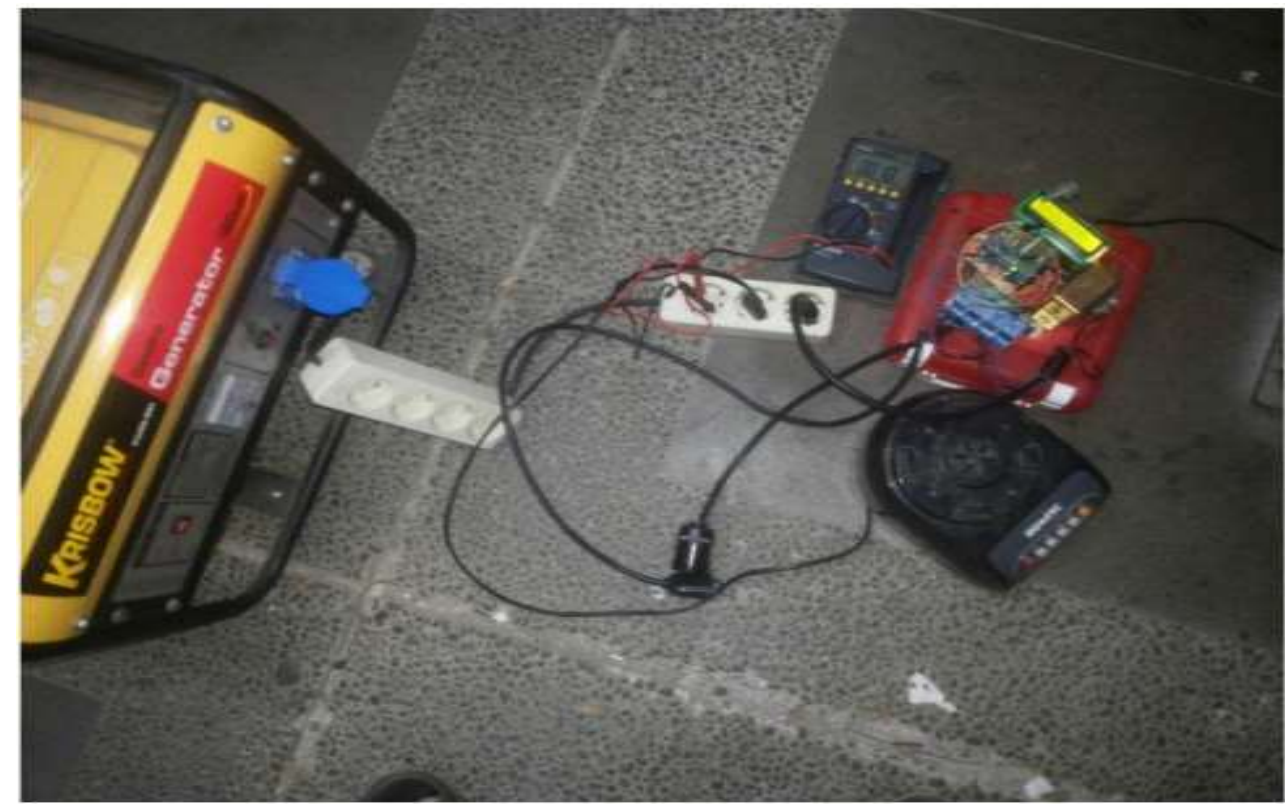

Gambar 11 Pengujian sistem dengan merubah-rubah nilai tegangan Generator Set

Pada Tabel 4. hasil pengujian ATS, relai berfungsi sesuai dengan nilai tegangan pada generator set, apabila sumber listrik cadangan (generator set) lebih kecil dari 220 Volt maka relai akan secara otomatis memindahkan sumber listrik ke PLN. 
Tabel 4. Pengujian ATS

\begin{tabular}{|c|c|c|c|}
\hline No & $\begin{array}{c}\text { Tegangan pada } \\
\text { Generato Set }\end{array}$ & Fungsi Relai & Beban Lampu \\
\hline 1 & 200 & Memindahkan ke sumber PLN & Tetap On \\
\hline 2 & 204 & Memindahkan ke sumber PLN & Tetap On \\
\hline 3 & 207 & Memindahkan ke sumber PLN & Tetap On \\
\hline 4 & 209 & Memindahkan ke sumber PLN & Tetap On \\
\hline 5 & 210 & Memindahkan ke sumber PLN & Tetap On \\
\hline 6 & 212 & Memindahkan ke sumber PLN & Tetap On \\
\hline 7 & 213 & Memindahkan ke sumber PLN & Tetap On \\
\hline 8 & 216 & Memindahkan ke sumber PLN & Tetap On \\
\hline 9 & 218 & Memindahkan ke sumber PLN & Tetap On \\
\hline 10 & 219 & Tetap menggunakan sumber cadangan & Tetap On \\
\hline 11 & 220 & Tetap menganganan sumber cadangan & Tetap On \\
\hline 12 & 221 & Tetap menggunakan sumber cadangan & Tetap On \\
\hline 13 & 222 & Tetap menggunakan sumber cadangan & Tetap On \\
\hline 14 & 224 & & Tetap On \\
\hline 15 & 227 & &
\end{tabular}

\subsection{Interface Perangkat dengan Web Server}

Pengujian komunikasi perangkat dengan Ethernet shield dilakukan secara serial bertujuan untuk mengetahui performansi kestabilan pengiriman data dari perangkat ke web server, pada Gambar 12 adalah hasil pengujian dapat diliat di website dengan alamat sesuai IP address Ethernet LAN.

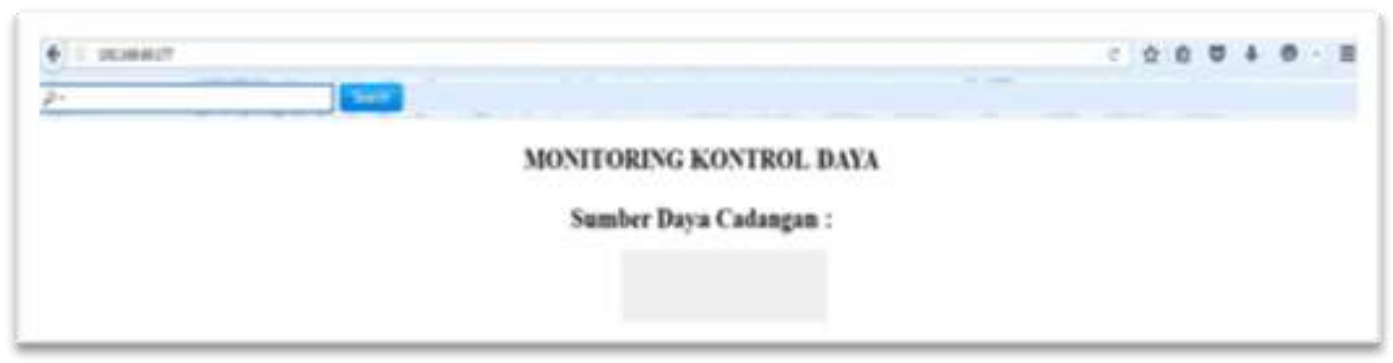

Gambar 12. Tampilan pada web browser

\section{KESIMPULAN}

Berdasarkan hasil pengujian, sistem keseluruhan pada ATS menggunakan Arduino dan relai dapat berjalan dengan baik, relai sudah berfungsi untuk memindahkan sumber listrik berdasarkan nilai tegangan dari sumber cadangan, tanpa membuat beban kehilangan arus listrik.

Terdapat error yang cukup tinggi dengan nilai rata-rata error adalah $3.76 \%$, terjadi pada blok pengukuran sumber tegangan cadangan, dimana pada pengujian ini menggunakan Generator Set, meskipun sudah melakukan beberapa pergantian rangkaian atau komponen pada sensor pembaca tegangan untuk mengurangi nilai error tersebut. Sedangkan apabila mengukur sumber dari PLN hasil pengujian memperoleh nilai rata-rata error sebesar $0.21 \%$, jauh lebih kecil dibandingkan pengukuran dari generator set.

\section{DAFTAR PUSTAKA}

[1] Susnato, E. 2013. Automatic Transfer Switch (Suatu Tinjauan). Jurnal Teknik Elektro Vol. 5 No. 1. Januari - Juni. 
[2] Diponkar Paul, Md. Shariful Islam, Syed Khalid Rahman, Md. Saiful Islam, Mir Mohiuddin. 2013. Performance Evaluation and Operation of Auto Load Transfer Switch. International Journal of Renewable and Sustainable Energy. Vol. 2, No. 6, pp. 205-211.

[3] Autade Prerana P., S. G. Galande. 2013. An Embedded1/3 Phase Automatic Transfer Switch Controller with Intelligent Energy Management. International Journal of Computer Technology and Electronics Engineering (IJCTEE) Volume 3, Issue 2, April 2013.

[4] Harahap A. P., Dwiono W., Harpawi N.. 2012. Rangkaian Perangkat Keras Pengalih Sumber Listrik Berbasis SMS. Jurnal Elektronika Industri Vol. 5, Desember, 40-49.

[5] Amuzuvi, C. K. and Addo, E. 2015. A Microcontroller-Based Automatic Transfer Switching System for a Standby Electric Generator. Ghana Mining Journal, Vol. 15, No. 1, pp. 85 - 92.

[6] Sultan S., Rana U., Ahmed I., Rabbani S. 2013. A New Technology of Online-Condition Monitoring of Energy Conservation Generation \& Loads. Smart Grid and Renewable Energy, 4, 18-22.

[7] Sistem minimum Arduino UNO. [online] tersedia di https://www.sparkfun.com/products/11021 [diakses pada tanggal 20 Desember 2016].

[8] Wicaksono, Handy. Relai - Prinsip dan Aplikasi pada Catatan kuliah "Automasi 1". Teknik Elektro Universitas Kristen $\quad$ Petra. Surabaya 